\title{
UNDESCENDED OVARY PRESENTED WITH PARAOVARIAN CYST
}

\author{
Guldeniz Aksan DESTELI ${ }^{1}$, Turkan GURSU ${ }^{1}$, Halime CEVIK ${ }^{2}$, Hulusi Bulent ZEYNELOGLU ${ }^{3}$ \\ 1 Department of Obstetrics and Gynecology, Baskent University, Faculty of Medicine, Istanbul, Turkey \\ 2 Department of Radiology, Baskent University, Faculty of Medicine, Istanbul, Turkey \\ 1 Department of Obstetrics and Gynecology, Baskent University, Faculty of Medicine, Ankara, Turkey
}

\begin{abstract}
SUMMARY
Undescended ovary is a rare congenital anomaly of female genital tract. Mostly seen as sample cases in the literature. Uterine or urinary tract anomalies may accompany this rare anomaly. Most cases are asymptomatic. We present an undescended ovary case with abdominal pain, whose ultasound and magnetic resonance imaging studies revealed a cystic mass, and laparoscopic findings were in favour of an undescended ovary.
\end{abstract}

Key words: ectopic ovary, laparoscopy, paraovarian cyst, undescended ovary

Journal of Turkish Society of Obstetrics and Gynecology, (J Turk Soc Obstet Gynecol), 2013; Vol: 10, Issue: 4, Pages: 272- 4

\section{PARAOVARYAN KIST ILE PREZENTE OLAN INMEMIŞ OVER}

\begin{abstract}
ÖZET
İnmemiş over, genitoüriner sistemin nadir görülen bir konjenital anomalisidir. Karşımıza genelde vaka sunumları olarak çımaktadır. Uterus veya üriner sistem anomalileri ile beraber olabilmektedir. Hastalar genelde asemptomatiktir. Tedavi gerekmez. Burada, ağrı ile başvuran genç bir bayan hastada abdominal ultrasonografi ve manyetik rezonans (MR) ile kistik kitle saptanan ve laparoskopi ile tanı konan bir inmemiş over vakası sunulmuştur.
\end{abstract}

Anahtar kelimeler: ektopik over, inmemiş over, laparoskopi, paraovarian kist

Türk Jinekoloji ve Obstetrik Derneği Dergisi, (J Turk Soc Obstet Gynecol), 2013; Cilt: 10, Sayl: 4, Sayfa: 272- 4

\section{INTRODUCTION}

Undescended ovary is a rare anomaly of the female genital tract and the exact incidence is not known. In some papers it was reported to be $0.3-2 \%(1)$. There are some case reports in literature. It is mostly a coincidental finding where ovarian function is not affected so contrary to undescended testis it is accepted as a variation. Diagnosis is usually put while searching for infertility by radiologic techniques or during surgery for ectopic pregnancy or a cyst ${ }^{(2-6)}$.

\section{CASE}

A 22 year old single patient with regular menstruation had lower-inferior quadrant pain which had increased recently. There was no defense or rebound but the abdomen was tenderness. Right ovary and uterus were normal at ultrasonographic evaluation but left ovary was not found at its normal localisation. There was an anechoic cyst with $8 \mathrm{~cm}$ diameter descending to paracholic region. MRI scans demonstrated a $8 \times 5 \mathrm{~cm}$ cyst with a thick wall exophytically arised from left ovary (Figures 1 and 2). Both of the kidneys, ureters and pelvicalyceal system were normal. Laboratory

Address for Correspondence: Dr. Güldeniz Aksan Desteli. Başkent Üniversitesi Tıp Fakültesi, İstanbul Hastanesi, Altunizade, Üsküdar, İstanbul Phone: +90(532) 6610775 e-mail: guldenizdesteli@hotmail.com

Received: 12 June 2012, revised: 15 May 2013, accepted: 24 May 2013, online publication: 28 May 2013 
tests showed that her leucocyte count was normal and beta-hcg was negative. Tumor markers were normal. Oral contraceptive use for two months was prescribed, at the and of 2 months period no change was observed at cyst size and her pain was increased so laparoscopy was planned. During operation, uterus, right ovary and fallopian tube was normal, cul de sac was deepened.left ovary was undescended and was at paracholic region. Upper pole of the left ovary was at paracholic space, lower pole was stuck to omentum and close to pelvic space. An $8 \mathrm{~cm}$ diameter paraovarian cyst with a thick wall was observed. Left tube was thin and elongated and fimbrial tip was edematous. No additional pelvic genitourinary pathology was observed. Laparoscopic cystectomy was made and cyst was seperated from ovarian cortex and tube. Pathology was reported to be serous cystadenoma.

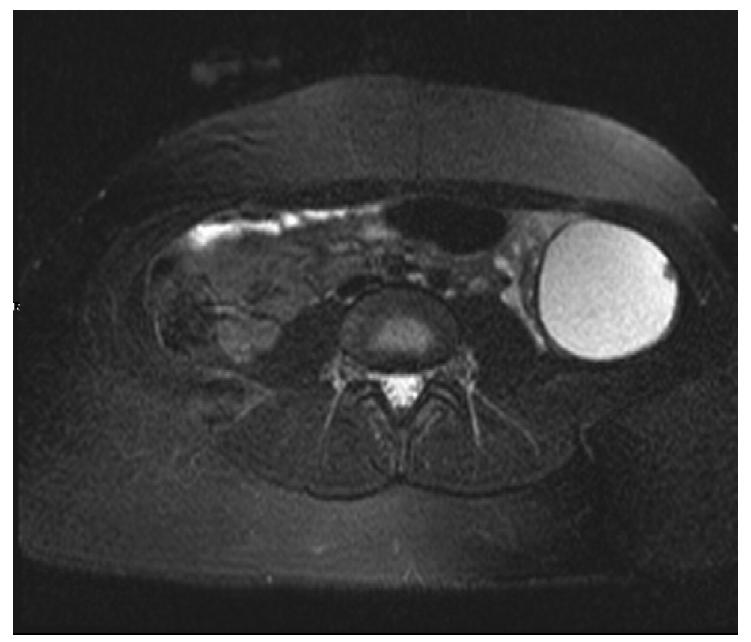

Figures 1:

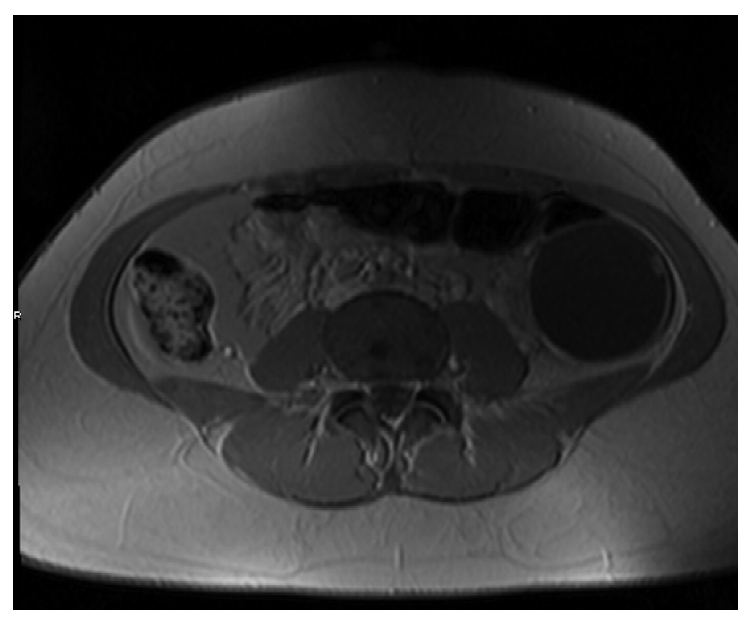

Figures 2:

\section{DISCUSSION}

Embryology of the female genital system has a complex structure and development. Gonadal development begins at 5 th week of gestation from gonadal process, overlying mesonephric process. Primordial germ cells do not arise from gonads between 4 to 6 weeks but migrate to the developing gonade by ameboic movement. At this phase of development male and female gonades are the exactly the same, indifferent and bipotent and has the potential to change into testis or ovary according to stimulating signals $(7)$.

At $5^{\text {th }}$ gestational week ovary starts to develop behind the peritoneal space and medial to the urogenital fold. It descends to fossa ovarica via the gubernaculum which is a mesenteric fold by chemotactic mechanisms and depending on the normal development of the mullerian system at 6 to $9^{\text {th }}$ weeks ${ }^{(8)}$.

In utero, at $5^{\text {th }}$ month ovaries are localized at iliac fossae and at at term, they are localized at pelvic inlet. They are at their normal place at postpartum period ${ }^{(9)}$. Undescended ovary occurs as a result of an interruption during the descendence or a pause at urogenital fold.

Ectopic ovary was first described by Evans at 1926(10). Other than paracholic region ovarian was also reported to be as an inguinal hernia, at left labium majus and even at omentum ${ }^{(11,12)}$.

Diagnosis of undescended ovary is difficult because they are generally asymptomatic. Radiologic imaging may help to put diagnosis. There are some cases detected by hysterosalpingography during investigation for infertility or MRI searching for pelvic pain $(2,4,5)$. Most of the diagnoses are put at surgery for ectopic pregnancy or cyst rupture $(3,14)$. Granat et al at 1981 reported first case of ectopic pregnancy at undescended ovary ${ }^{(14)}$. Kive reported hemorrhagic cyst rupture at a 13 year old patient with undescended ovary ${ }^{(3)}$. Our patient had pelvic pain and paraovarian cyst was found. And during operation ovary was found at paracholic space. As far as we know it is the first case presented with a paraovarian cyst. Genitourinary anomalies especially uterine malformations may accompany in patients with undescended ovary.Rokitansky-KüsthnerHauser Mayer syndrome may be seen 20\% and uterine unicornus $43 \%(15)$. At unilateral undescended ovary usually contralateral unicorn uterus is seen, ipsilateral tube is usually distant from uterus and only distal 
fimbria exists ${ }^{(4)}$. Normal but elongated or rudimentary tube may exist at bilaterally undescended ovaries ${ }^{(16)}$. At $25 \%$ of the patients some disorders other than genital anomalies are seen, mostly they are renal system anomalies like agenesis $(10,17)$. Rarely anomalies of colon or appendix may be seen ${ }^{(18)}$, so MRI investigation of other systems is advised ${ }^{(2)}$. In our case there we did not observe any additional systemic anomaly other than elongated tube.

Treatment of undescended ovary is conservative, ovary is not needed to be excised. Some authors suggested denervation of ovary but due to the difficulty of the technique and insufficiency of literature knowledge it is not common(16). Continuous treatment with oral contraceptives is advised for patients with pain(3). Assisted reproductive techniques are advised for patients with uni or bilateral undescended ovary and tubal pathologies. In patients with pain, if ovarian tissue is not found at its normal localization undescended ovary should be kept in mind. More reports on this issue are needed.

\section{REFERENCES}

1. Dietrich JE, Hertweck SP, Bond S. Undescended ovaries: A clinical review. J Pediatr Adolesc Gynecol 2007 Apr;20(2): $57-60$.

2. Trinidad C, Tardaquila F, Fernandez GC et al. Ovarian maldescent. Eur Rad. 2004 May;14(5):805-8.

3. Kive SL, Perlman S, Bond S. Ruptured hemorrhagic cyst in an undescended ovary. J Ped Surg 2004 Nov;39(11):e4-6.

4. Van Voorhis BJ, Dokras A, Syrop C. Bilateral undescended ovaries: Association with infertility and treatment with IVF. Fertil Steril; 2000 Nov;74(5):1041-3.

5. Görgen H, Api M, Delikara N. Undescended fallopian tubes and ovaries: a rare incidental finding during an infertility investigation work up. Acta Obstet Gynecol Scand 2002 Apr; 81(4):371- 4 .

6. Seoud M, Khayyat H, Mufarrij I. Ectopic pregnancy in an undescended fallopian tube: an unusual presentation. Obstet and Gynecol 1987 Mar;69(3 Pt 2):455-7.

7. Motta PM, Makabe S, Nottola SA. The ultrastructure of human reproduction. I. The natural history of the female germ cell: origin, migration and differentiation inside the developing ovary. Hum Reprod Update 1997 May-Jun;3(3):281-95.

8. Yoshinaga K, Hess DL, Hendrickx AG, Zamboni L. The development of the sexually indifferent gonad in the prosimian, Galago crassicaudatus crassicaudatus, Am J Anat 1988 Jan, 181(1):89-105.

9. Speroff L, Fritz M. The ovary embriyology and development, Clinical Gynecologic Endocrinology and Infertility 7th Edition, Lippincont Williams and Wilkins 2005 p.97-106.

10. Evans A, Cade S. Ectopic ovary. Br J Surg. 1926;13:182.

11. Kent S. Retroperitonesl tube and ovary associated with inguinal hernia: Report of a case. Obstet Gynecol 1963 Feb;21:234- 7.

12. Machiels F, Maeseneer M, Desprechins B et al. Unusual location of an ovary: ultrasonographic features and surgical correlation. J Belge Radiol 1998 Dec;81(6);288.

13. Kriplani A, Takkar D, Karak AK. et al. Unexplained absence of both fallopian tubes with ovary in the omentum. Arch Gynecol Obstet 1995;256(2):111-3.

14. Granat M, Evron S, Navot D. Pregnancy in heterotopic fallopian tube and unilateral ovarian hyperstimulation. Acta Obstet Gynecol Scand. 1981;60(2):215-7.

15. Verkauf BS, Bernhisel MA. Ovarian maldescent. Fertil Steril 1996 Jan;65(1):189-92.

16. Milnes-Walker R, Lond M. Undescended ovaries. Lancet 1935;229:1346-7.

17. Adponoz A, Davis J. Torsion of an ectopic ovarian cyst complicating early pregnancy: Discussion of unusual anatomy and etiology. AMA Arch Surg 1951 Feb;62(2):292-4.

18. Pidcock B. An abnormal large intestine with imperfectly descended ovaries. Br Med J 1930;2:863-4. 